\title{
Integrated higher learning-An investment in intellectual capital for livestock production
}

\author{
N.H. Casey $*$ \\ Department of Animal and Wildlife Sciences, University of Pretoria, Pretoria 0002, South Africa
}

\section{A R T I C L E I N F O}

Available online $\mathrm{xxxx}$

\section{Keywords:}

Animal science

Education

Training

Intellectual capital

University curricula

\begin{abstract}
A B S T R A C T
Intellectual capital (IC) is a key concept to sustaining a global livestock industry. Accumulated IC in animal science has contributed to successfully developing an efficient global industry, but that has come at a cost to the environment. The challenge is to develop IC to address the negative aspects of the livestock industry, yet continue the advances towards more efficient livestock production and improved qualities of livestock products. Investments in IC to sustain the livestock industry must not only be technical of an animal science nature, but should include external constituencies such as customers and various other associated entities. IC for the livestock industry is required at different levels that range from labourers to university science graduates. Undergraduate and postgraduate education in animal science must be designed to meet the objectives of a sustained career development and the ability to address the challenges facing the livestock industry. There need not be only one type of graduate, but curricula can be adapted to provide graduates with a different focus and clearly defined output objectives of curricula designed in consultation with the industry. IC and professional development programmes would benefit from unconditional cooperative programmes between universities, professional science societies and the industry. The future of the animal industry is dependent on the effective acquisition and application of the appropriate IC that includes the three dimensions being people and their competencies and knowledge, the organizational and management systems, and external constituencies.
\end{abstract}

(c) 2010 Elsevier B.V. All rights reserved.

\section{Introduction}

Animal agriculture fulfils interesting roles in human society. First, it is a human cultural heritage that is translated into the bond and inter-dependence between people and their domesticated animals. Second, it is a vast, collective business enterprise. The livestock industry is an essential and integral component of regional and national economies. Over centuries humans had acquired a rather basic knowledge of animal husbandry practices. The practices were low key and of low intensity that fed, clothed and gave draught power to nations. Animal husbandry was practiced with a high regard for the environment because the whole system had to be sustaining, even if it had to contend with variability in climate

\footnotetext{
* Tel.: + 2712 4204018; fax: + 27124203290 .

E-mail address: norman.casey@up.ac.za.
}

and weather patterns. The knowledge-base for successful husbandry was passed along by traditions and apprenticeships in farming communities. However, the industrial revolution was soon to challenge agriculture. Agriculture had to draw benefits from and provide benefit to this technological revolution.

This paper considers the intellectual capital required in animal science, the expectations of students and approaches toward instilling skills through education and research.

\section{Industrial revolution and knowledge evolution}

The livestock industry has been part of the industrial revolution for the past 250 to 300 years. Since the dawn of Neolithic agriculture, animals have been a dependent source of food, power and other useful animal products. Breeds and types came about within regions, associated with smaller 
clusters of human settlements through incidental breeding that resulted in similarly looking livestock populations. A celebrated agriculturalist set a tone for the later successes in agriculture. In the latter part of the 18th Century, Robert Bakewell (1725 to 1795) realised the value of deliberately breeding and selecting livestock for production traits and feeding them accordingly (Wood and Orel, 2005). This coincided with the beginnings of the industrial revolution. Though revolutionary, Bakewell's deriving new techniques brought about an evolution in animal agriculture. The concepts for improving livestock that he pioneered remain to the present.

The advantages gained showed that livestock production could be manipulated to be more efficient and produce a type of animal that improved the farm's production capabilities and efficiency. Coinciding with the industrial revolution the improved production that was attained fuelled the nutritional needs of the burgeoning population (and likely contributed to the human population growth), and the improved quality of draught animals provided more animal power.

The successes demonstrated that a basic level of knowledge had been brought forward to Bakewell, who had the insight gained from an extensive education and farming experience to begin experimenting with livestock until he had bred an improved and distinct breed of sheep, the Leicester. Since then, many, many livestock producers have capitalised on these fundamental principles and advanced the livestock industry to the current remarkable position.

At present, the global livestock industry contributes to sustaining a human population of $>6$ bn people. It contributes $40 \%$ of the agricultural gross product in terms of Gross Domestic Product and provides about a third of humanity's protein. Through the study of livestock physiology and nutrient requirements and the application of the principles of breeding and selection for production traits and survival within a specific environment and production system, the efficiency of production has been pushed virtually to the animal's physiological limits (Gous, 2009; Webb and Casey, 2009). The gain in efficiencies has been supported by collateral factors such as nutritionally improved pasture crops, the mass scale production of grains used for animal feed that are nutrient dense, and mechanisation that has facilitated intensive production systems. The most effective driver towards the gains in efficiencies has been the growing demand for livestock products by more urban and affluent societies. But this has come at a cost.

\section{Livestock's long shadow}

The publication "Livestock's long shadow-environmental issues and options" (Steinfeld et al., 2006) draws attention to the high impact that livestock production has had and is having on the natural environment. The publication refers in passing to a negative effect of livestock products on human health, namely obesity, and sidesteps the positive effects of meat, milk and eggs being nutrient dense foods. The document does acknowledge the fact that the sector provides employment and poverty alleviation to millions of people. However, the noted contributions of livestock to greenhouse gases $\left(\mathrm{CO}_{2}, \mathrm{CH}_{4}\right.$ and $\left.\mathrm{N}_{2} \mathrm{O}\right)$, to land degradation through grazing malpractice in combination with variable weather conditions that lead to prolonged droughts, the use of potable water (also depleting groundwater reserves) and the loss of terrestrial biodiversity, remain contentious issues.

Recent controversies have been (i) the increasing need of safety, quality and traceability of livestock products, (ii) the safety of animal feed and water and minimising the risks to animals and consumers by avoiding malpractices such as, for example, recycling animal products into animal feed and including potentially toxic substances to seemingly increase nutrient content (crude protein in the form of melamine), (iii) the use of grains that could be human food for animal food and (iv) the use of grains that could be converted to human food for bio-fuel. The changing demographic, political, economic and social profiles of consumers contribute further to the dilemma facing livestock production.

Intellectual capital within the livestock industry was gained from traditional knowledge and the natural, economic and social sciences. This intellectual capital has brought about the transition of livestock production from a fairly placid rural occupation to a mainstream global economic enterprise.

The question is whether it is possible to continue the transition and to increase production capacity and efficiency in order to meet the future expectations for animal products (World Bank Report No 44010-GLB, 2009), and at the same time address the negatives associated with the livestock industry (Steinfeld et al., 2006). How best can the intellectual capital be applied to face these challenges?

\section{Intellectual capital}

A view on business strategy has emerged over the past half century that emphasises resource efficiency rather than generally accepted competitive forces. It is recognised that enterprises, including the livestock industry, have differentiated, unique resources and capabilities (Sullivan, 2000). A resources-based perspective is focused on strategies for exploiting existing and specific assets, and, since some of the assets are intellectual, the acquisition of skills and the management of knowledge and learning become fundamental strategic issues. In this context, Sullivan (2000) reached the conclusion that dealing with invisible assets or human capital, may have enormous potential for contributing to business strategy.

Intellectual Capital (IC) by definition is collective knowledge individually or collectively in an organization or society that can be used to produce wealth, multiply output of physical assets, gain competitive advantage, and/or to enhance the value of other types of capital. IC has developed in concept as an asset and a resource essential for the growth and development of an industry. It may be classified as a true capital cost (BusinessDictionary.com, 2009), because investments in people are as investments in facilities, and it may be considered that expenses incurred in educating and training people in order to maintain the shelf-life of intellectual assets, are equivalent to depreciation costs of physical assets.

Much of the thought on IC focuses on how IC is created and how it is leveraged into economic value and social value (Roos et al., 1997; O'Donnell et al., 2003). These are complex and specific. For example, it would stand to reason that the IC of a person providing a service within a specific context as within the livestock industry, comprises both learned and 
experiential knowledge that interact with personal characteristics and with the environment (physical, intellectual, business, and cultural). O'Donnell et al. (2003) consider that interaction between people is a critical source of intangible value in contributing to an individual's IC and that of the collective. These authors noted that the modern business sector undergoes rapid change in the face of an accelerating pace of technological change, and that business, including agribusiness, operates in uncertain organizational zones. This is coupled with re-segmentation and redefinition of regional and global markets.

IC may be separated into three dimensions:

- People-referring to competencies, knowledge, know-how, adaptability, network connections and experience;

- Internal-referring to the set of inner organizational routines, processes, culture, structures, management systems; and

- External-referring to external constituencies such as links to customers, suppliers, outsource partners, strategic alliances, research institutes and various other external networks linked into the IC creating or leveraging value chains.

These have a positive relationship with business performance (O'Donnell et al., 2003).

The question that arises is the extent to which investments in IC sustain the livestock industry. The livestock industry has specific, proven benefits to the human population: It provides economic and social security; offers employment opportunities to a wide range of skilled, semiskilled and poorly or unskilled people; is based on the use of natural resources, for example, harvesting and converting plant material that is not suitable as a human food into animal products.

The livestock industry in localised situations most certainly capitalises on indigenous knowledge (indigenous IC). Further, the livestock industry is a force for distributing knowledge, and for introducing advanced technologies that might have been developed locally or imported (acquired IC). Being totally integrated with the economy, requiring people to run it from the most menial to the most complex task and being dependant on the natural resources, there is hardly a discipline or skill that could not be accommodated in the animal industry (Casey, 1996).

Consumers in highly urbanised societies are poorly connected to the agricultural industry. Their understanding of the dynamics of agriculture is more ideological than practical, and consequently nurture ideological expectations of production systems and product quality. In order for the agricultural industry to reach out successfully to consumers, a consumer IC must be invested in-the external constituencies referred to (O'Donnell et al., 2003). The livestock industry consequently relies on a collective IC that encompasses the entire value chain, from production to consumption.

\section{Education as a tool for the livestock industry}

Education and research are for tomorrow, not for today. These are the investments society makes in its future. And, society must have confidence in its teaching and research institutions to achieve these objectives.
Training for the animal industry falls within four levels and three directions. The four levels are (i) semi-labourer that are literate, (ii) graduates with basic animal husbandry skills from colleges that would require two to three years of secondary schooling, (iii) technically skilled graduates from technical colleges or technikons (technicians), and (iv) university science graduates.

The three directions are (i) general animal production, (ii) animal health, and (iii) resources utilisation.

The levels are defined according to a candidate's academic potential and aptitude, and the directions according to the service to be rendered. The skills-need for the industry is pyramidal with the largest ratio being in the semi-skilled region followed by animal husbandry skills, technicians and lastly, science graduates.

\section{Students}

In training professional people at the science graduate level, three issues are at stake: first the expectations of the students; second the expectations by the industry of animal science graduates, and third the expectations of the graduates by the public at large.

The question most often raised by prospective students and enquiring parents is what can be done with a qualification in the field of animal agriculture, and is the qualification recognised internationally. Second to these questions are issues like employment opportunities, the working environment such as working indoors or outdoors, gender, racial or social discriminations, and working with animals or people. There is the question of specialising in animal science nutrition, animal science breeding, genetics and conservation of rare genotypes, animal science production physiology, livestock products (meat, milk, eggs, fibre and others), resource management, extension services, research, teaching and wildlife options, or possible associations with other professionals such as veterinarians, economists and social scientists.

The premise is that students decide on a specific direction of study based on the assumption that there must be something in the direction that makes the study worthwhile, or that the investment in time and money will yield expected returns in terms of financial earning capacity, competitiveness, personal satisfaction and security. The prospective professional's first concern is self interest. Respondents to a survey commissioned by the South African Society for Animal Science indicated that interest was the main reason for choosing animal science as a professional study option (Hirschowitz, 1986).

The question is: Are they satisfied with their chosen direction and the training they received if viewed retrospectively after having travelled some distance down life's road? The young people interviewed annually, men and women of all ethnic groups, are full of vitality. Their expectations are hardly ever that they would someday be forced by circumstances to settle into full-time employment; that their "baggage", and here the Latin word impedimenta describes it more appropriately, could get heavier before it got any lighter. Their emotions are elated being among the relative few who qualify for a college or university education. They are stimulated by the adventure of being at college or university, 
academically and socially. The goals are short term: the paper, the examinations, and the degree. In the distance is the vision of being a professionally qualified graduate. The day then dawns for finding employment, and the next day of coming to terms with the conditions of employment, and the next day of advancing along the professional track, until the day of reckoning when the graduate takes stock of the path followed.

As is human nature, if the experiences have been good and the overall impression is favourable, the road travelled would seem to have been a good one, but if not, the road will have been a dreary one-right back to their university education! The survey commissioned revealed $84 \%$ were satisfied with their chosen direction, with some reservations about their education, and only $16 \%$ were actively engaged in leaving the field (Hirschowitz, 1986). There may be some bias in the survey, since the respondents were virtually all white South Africans. However, the assumption is that professional people have the same expectations irrespective of gender or ethnic group, particularly if their education had been similar. The respondents occupied positions throughout the industry as professional technical advisors in animal science, or as extension personnel, researchers or managers in corporations, government or parastatal institutions, as farmers, resource and commodity brokers in the animal industry and as teachers at secondary and tertiary institutions.

Students who choose agriculture or who are guided into it had a preference for the natural sciences during their secondary schooling. Mathematics, science and in some instances biology, are prerequisites for entrants into the natural sciences, including animal science, at university. By setting high entrance criteria with these subjects as prerequisites the emphasis on the natural sciences is maintained.

\section{Objectives in animal science training}

Training is an important topic among animal scientists. In 1988 this was the theme of the annual congress of the South African Society for Animal Science. The President of the Society, Dr F M C Gilchrist, expressed the view in an opening address that "training must provide a broad base of profound scientific knowledge from which to draw on in decision making throughout a life-time career. In training the emphasis is on principles and how to acquire factual data (through research)" (Gilchrist, 1988). De Lange (1988) reported that the animal science departments at South African universities follow the same core animal science subjects, but that they differed in their definition and extent of practical training, which is still the case in 2009. Richardson (1988) took a global view of animal science training and concluded that the task of animal scientists is to improve the viability of production (and processing): "graduates should be equipped to assess the environmental constraints scientifically, (which may require) moving away from empirical to a quantitative knowledge (base) of animal physiology and metabolism".

The animal industry consists of three defined sectors: primary production, product processing and distribution, requiring general and specialised skills. The needs of the various branches of the industry have a common message, which Griessel (1988) listed as: A strong background in the basic sciences; an in-depth knowledge of the literature in any field of specialisation with the correct interpretation; an understanding of production economics; handy skills such as being computer literate. Lombard (1988), in discussing the needs of the meat industry, noted that apart from the basic animal sciences, graduates should be able to come to grips with the culture of the specific industry, which includes the customer, in order to be able to contribute to improving production economics, meat quality, processing, marketing and, one may add, the nutritional value of meat products. Kingwill (1996) noted that few managers of large enterprises do not have tertiary education, implying a diploma or degree. The essence is that knowledge and expertise (i.e. I.C.) are critical for sustainability.

Chickering (1996), in discussing the roles of universities towards empowering students for life-long self development, states that successful careers call for (self) motivation, interpersonal competence and well-developed cognitive skills, which includes critical thinking, conceptualising and high level oral and written communication skills. Integrating communications into natural science-based courses and in agriculture where graduates need highly developed reading and speaking skills and a good use of language to facilitate their achievements in industry (Orr, 1996). Animal science graduates with good communication skills would gain personal and professional advantages with improved academic achievement, attitude and confidence levels and in their ability to apply and use animal science concepts.

The foregoing views were considered fundamental requirements in the training of animal scientists for the purpose of achieving professionalism in South Africa (Vosloo and van der Merwe, 1976). The common denominator of curricula at the various institutions is a theoretical and applied knowledge in animal physiology, animal breeding and genetics and animal nutrition, supported by animal management and technology courses (for example, evaluating semen, artificial insemination, pregnancy diagnosis, wool classing, and evaluating livestock for functional efficiency), biochemistry, economics, genetics, biometry and soil, pasture and crop sciences (Vosloo and van der Merwe, 1976).

As a result of the combined efforts by the industry, academic institutions and the South African Society for Animal Science, the animal science curricula at South African universities have become similar with a first year of basic sciences (chemistry, mathematics, physics, and biological subjects), which is followed by a core of animal science subjects and the supporting courses. Academic freedom and the availability of various courses and specific skills, results in some universities including other supporting courses such as agro-meteorology, communication skills and computer science.

In order to ensure that qualifications for professional registration in the natural sciences have a high natural science content, the South African Council for Natural Scientific Professions has set criteria for natural science degrees that fall within its mandate (Act 27, 2003), including animal science. The minimum academic credits in the natural sciences in the 1 st year should be $70 \%$, followed by $80 \%$ in the 2nd and 3rd years and in the 4 th year preferably $100 \%$ with at $80 \%$ directly associated with the principle discipline (SACNASP, 2009). These criteria allow for the inclusion of other courses that would be considered valuable in the total 
education of the graduate, for example, business and personnel management, marketing, etc. The graduates in animal science emerge with a broad-based education in agriculture with a focus on animal science, and complimented with other skills.

The question is whether there are deficiencies in this model. Introspection and an assessment of the relevancy of the curricula are and must be an ongoing process taking into consideration new technologies and estimated requirements of future skills. The University of the Orange Free State reviewed their curriculum, motivated by the results of Macadam and Bawden (1985) according to Wilke (1992). Macadam and Bawden (1985) reported a mismatch for the Australian environment between training and perceived needs of the industry and identified the need for more practical skills and an understanding of farming operations and their interactions. However, the components of the restructured curriculum presented by Wilke (1992) did not differ essentially from the traditional animal science curriculum.

On the question of responding to contemporary issues, Swanson (1999) reported that Land Grant Universities in the US responded to these public and scientific issues, for example, water pollution, animal waste, animal welfare, and food safety, but that inclusion in programmes at postgraduate level was often lacking. On the graduate level the response may not be delayed in the theory components, but in the research components that are dependent on external funding. However, the survey did establish that research projects reported in the survey were in alignment with the primary issues facing the agricultural animal industry, e.g., animal waste. Swanson (1999) reiterated the opinion of Westendorf et al. (1995) that agricultural research should remain responsive to societal concerns and broaden the constituencies with whom the research is conceived. Although many of the responses were not surprising, the efforts toward conducting social research were (Swanson, 1999).

It would be reasonable to assume that the results reflect the responses to contemporary issues by all academic departments of animal science globally within their capabilities.

Livestock production in Africa straddles a vast cultural difference with traditional subsistence and commercial farming existing side by side (Casey, 1993). Small-scale agricultural units including livestock (chickens) are also present in the peri-urban areas. This presents particular challenges in equipping animal science students. Swanepoel (1990) presented a case that the undergraduate curricula should include developing and subsistence agriculture, reiterated by van den Bor (1996). In addition there is a political tendency to give preference to development and subsistence agriculture for the purposes of keeping people productive on the land and stemming the migration to the cities where many can only afford to live in shanty town settlements. However, the principles of animal production remain the same irrespective of whether the animals are in commercial, subsistence or urban agricultural systems.

Similarities between commercial agriculture and smallscale livestock producers (Casey, 1993) are such that both:

- Draw or can draw from the same animal genetic pool;

- Need to provide feed with a minimum nutritive value, in adequate amounts throughout the year;
- Wage a constant battle against parasites and diseases;

- Are subjected to the conditions of the regional and national economy;

- Keep a core of livestock either for production or for capital value;

- Are forced to convert livestock or the products into ready cash to finance other commitments;

- Should strive for optimum efficiency within the parameters of their cultural and production systems.

However, the dynamics of the systems can affect their relative productiveness. In small-scale agriculture, resources become the limiting factor. It would be reasonable to consider that in addition to being schooled in the biological attributes of livestock, students should gain an understanding of the differences in the dynamics between small-scale and largescale commercial systems.

\section{Being prepared for the industry}

It would seem a dichotomy exists between academics and graduates on the issue of whether graduates are adequately or inadequately prepared for service in the industry. The impression gauged from the survey of animal scientists (Hirschowitz, 1986), by the demand for animal scientists, by feedback from the industry and by the positions to which graduates have progressed nationally and internationally, suggested that the model had delivered the right type of person with the right type of technical skills. All respondents (171) to the survey agreed that graduates should be adaptable to any work situation, thereby implying a broad basic education. However, 67\% indicated that they felt their training had been deficient and the most frequently identified deficiency was that training was not related to the work situation, and $15 \%$ said their training lacked academic content (Hirschowitz, 1986).

Surveys of this nature should be interpreted carefully, because there may be undisclosed reasons why some graduates are positive and some negative about their education. Stielau (1989): “... the animal industry has many facets and therefore demands practitioners with a wide range of skills. No training programme can, given the time available, produce graduates equally expert in all the possible directions that exist within the industry. I doubt whether any faculty should attempt to do so. A university is not there merely to provide professional training. Rather we should aim at providing the industry with well prepared, cultured students who understand both technical and applied problems in animal science and who are able to expand their knowledge and expertise independently while practising their chosen profession. Employers must understand that it will seldom be possible to provide them with students specifically tailored to their unique requirements".

\section{Curricula}

Designing of curricula has traditionally been under the guise of academic freedom, the privilege of academia. It would be folly to take this responsibility from the academics responsible for the teaching programmes. The academics, however, have a responsibility towards the students, 
the industry and the public at large to ensure that the curriculum is technically relevant and instils the correct knowledge in the students, promotes enquiring minds, factuality and creativity. This means consultation with role players in the industry, consultation with scientific specialists of the various disciplines in the curriculum, consultation with representatives of the public such as consumer groups, and periodic reviews.

Academics must take note of shifting paradigms in the agriculture industry and in public sentiment towards science, animals and animal products when reviewing curricula (Braund, 1995) and not only focus on new technologies. Kauffman (1992) considered that an animal science curriculum is a "moving target" due to changing needs and demands of our society and, more specifically, to changes in the backgrounds and interests of students, and that animal science curricula must change, if they are to succeed.

In the United States of America, the land grant colleges and universities have come under scrutiny. Although Africa is vastly different from the USA in its social and economic structure, democracy is growing and with it public accountability. It is worthwhile taking note of the sentiment towards these institutions in the USA because sooner or later Africa will have to face these issues. According to Weber et al. (1995), the sentiment is that the traditional focus on agriculture alone is less relevant to the general public and, to be relevant, the colleges and universities need to develop a more societal-based, problem solving focus that includes agriculture and food in the broader matrix of issues facing society. These include food safety and quality, environmental impacts of agricultural production, the role of animal products in a healthy diet, animal welfare/rights in the context of the use of animals for food production, global competitiveness, the social-economic impact of new technologies on the structure of agriculture, i.e., the external constituencies.

\subsection{Undergraduate curricula}

The objective would be to produce a graduate with the knowledge and ability to develop a career in a scientific/ academic research field or to be a practising animal scientist in the industry with the ability to adapt to new challenges. Three types of undergraduate curricula for the animal agriculture industry are presently functioning at South African universities, excluding veterinary science, that cater for three different entrance levels and output objectives, namely the BSc(Agric) and BAgric that are products of standard academic universities and a BTech that is the product of the universities of technology.

The $\mathrm{BSc}$ (Agric) is the traditional four-year scientific programme, with a strong foundation in the fundamental sciences (chemistry, mathematics, physics, biology, and biochemistry) and applied disciplines of animal anatomy, physiology, nutrition, breeding and ecology, animal products and species specific husbandry practices. A reference framework curriculum for a standard animal science curriculum adapted from the curriculum of the University of Pretoria (U. P. Yearbook, 2009), is shown in Table 1.

Graduates from the BAgric and BTech programmes, fall into the category of administration and technical and extension services. Enrolment requirements for the BAgric and BTech are lower in mathematics and science than for the $\mathrm{BSc}$ (Agric).

Animal science is an applied professional direction. Education programmes for the profession require curricula that are well-balanced between theory and practice. The practice side is gained through directed field work. Honeyman and Miller (1998) having investigated the effect of teaching approaches on achievement and satisfaction of fielddependent and field independent students, concluded that a balanced approach of field-dependent and field independent teaching approaches benefitted student achievement optimally.

The University of the Free State, South Africa, offers a programme in animal science or livestock production that comes close to being vertically integrated (Table 2). This vertical integration may not be a suitable model for regular academic universities, but it does illustrate the levels of IC required for integrated higher learning being an investment in IC at different levels of competency (U.O.F.S. Yearbook, 2010).

\subsection{Post graduate curricula}

Post graduate training is both an advanced study in animal science and the first step towards specialisation. A post graduate programme may be complex because two objectives are to be achieved: delivering a graduate with advanced competencies and advancing the scientific status of the institution that is a consequence of the research for which post graduate students are an indispensable resource. Scientific status draws new students and other resources. Furthermore, the respective universities are situated in different agro-ecological regions and it is correct that the issues of the region are addressed by the local university. This provides the opportunity for centres of excellence/expertise.

Research programmes are closely aligned with master's and doctorate students. There should be no limits to the focus of research programmes. Research is either explorative or needs-driven and the type of research undertaken is determined by available resources and opportunities. It remains important that the principles of scientific research are not only maintained in the scientific journals, but equally in industry specific magazines and communicating pamphlets for the benefit of the industry and extension services. Creditable science-based articles in industry oriented publications promote the credibility of the animal science profession and that of the industry.

\subsubsection{Masters degree}

Studying for the master's degree is the first real step to specialisation. Holt (1987) notes that the professional track is dominated by master's degrees, "which are important and sometimes required in our society for professional advancement and development". The master's degree is by tradition based on research leading to a dissertation. The situation regarding post graduate students is changing, however, some of the younger graduates may still undertake their advanced studies full-time, but personal liabilities are restricting candidates from undertaking full-time study. There is therefore a need to accommodate these people in a more 
Table 1

Reference framework curriculum for standard four-year degree in animal science.

$\begin{array}{ll}\text { Year } 1 & \begin{array}{l}\text { Natural science } \\ \text { courses }\end{array}\end{array}$

General chemistry

Molecular and cell biology

General physics

Mathematics

Biometry

Plant biology

Introductory genetics

Introduction to microbiology

Animal diversity

Animal science

Other courses

Computer literacy

Academic and information

literacy

Year 2 Natural science courses

Biochemistry

Animal science anatomy and physiology

Introductory soil science
General introduction to inorganic and analytical chemistry that includes nomenclature of inorganic ions and compounds, stoichiometric calculations, redox reactions, solubility, atomic structure, periodicity, inorganic and physical chemistry, molecular structure, chemical bonding using the VSEPR models, chemical equilibrium, acids and bases, buffers, precipitation. General physical-analytical chemistry, physical behaviour of gases, liquids and solids, intermolecular forces, solutions. Organic chemistry, structure (bonding), nomenclature, isomerism, introductory stereochemistry, introduction to chemical reactions and chemical properties of organic compounds and biological compounds, i.e. carbohydrates, lipids and amino acids. Supplemented with laboratory-based experiential training (SLET).

Introduction to ultra-structure, function and composition of representative cells. Principles of cell metabolism, growth, division, differentiation, and molecular genetics. SLET.

Intended for one semester requirements of physics, includes units, vectors, one dimensional kinematics, dynamics, work, equilibrium, sound liquids, heat, electric potential and capacitance, direct current and alternating current, optics, modern physics, radio activity. SLET.

Intended as terminal 1st level, includes functions, derivatives, interpretation of the derivative, rules of differentiation, applications of differentiation, integration, interpretation of the definite integral, applications of integration, discrete probability, matrices, solutions of systems of equations. Markov chains.

Simple statistical analysis: Data collection and analysis: Samples, tabulation, graphical representation, describing location, spread and skewness. Introductory probability and distribution theory. Sampling distributions and the central limit theorem. Statistical inference: Basic principles, estimation and testing in the one- and two-sample cases (parametric and non-parametric). Introduction to experimental design. One- and two way designs, randomised blocks. Multiple statistical analysis: Bivariate data sets: Curve fitting (linear and non-linear), growth curves. Statistical inference in the simple regression case. Categorical analysis: Testing goodness of fit and contingency tables. Multiple regression and correlation: Fitting and testing of models. Residual analysis. Computer literacy-computer packages in data analysis and report writing.

Basic plant structure and function; introductory plant taxonomy and systematics; principles and application of plant molecular biology; ecosystem; adaptation of plants to extreme environments; medicinal compounds from plants; introduction to range evaluation and management. SLET.

Principles of Mendelian inheritance, introductory cytogenetics, karyotype, cell division, probability studies, genetic linkage, chromosome mapping, sex determination, sex linked traits, inheritance of cytoplasmic DNA, cytoplasmic effects.

General anatomy and morphology of bacteria, viruses and fungi. Micro-organisms in ecospheres: plant, water and soil ecosystems. Micro-organisms in food preservation decay, poisoning. Principles of disinfection, sterilization, control of microbes. SLET

Animal classification, phylogeny, organization, terminology, evolution of various animal phyla, morphological characteristics, life cycles of parasitic and non-parasitic animals, comparative structure and function of selected vital systems.

Introduction to the livestock industry that includes basic principles and terminology, livestock production regions and systems, livestock species, breeds and products, principles of livestock production, society and animal agriculture.

Introductory general computing concepts and computer competency. SLET

Introduction to academic literacy, various language learning styles and strategies, initial exploration of academic language, academic listening and speaking, collecting and processing information for academic tasks, academic vocabulary with writing practice. Information resources, quality and use-interpretation, ethics, plagiarism, copy right, referencing techniques.

Amino acids, peptides, peptide bond, structure of proteins, stabilization, denaturation and renaturation of proteins, purification methods, amino acid composition, and sequence determinations, introduction to enzyme kinetics and enzyme inhibition, allosteric enzymes, regulation of enzyme activity, active centres and mechanisms of enzyme catalysis. Carbohydrates, thermodynamics and bioenergetics, glycolysis, citric acid cycle, electron transport, glycogen metabolism, pentose-phosphate pathway, gluconeogenesis and photosynthesis. Metabolic pathways and enzymes. Lipids, membrane structure, anabolism and catabolism of lipids. Nitrogen metabolism, amino acid biosynthesis and catabolism. Biosynthesis of neorotransmitters, pigments, hormones and nucleotides from amino acids. Catabolism of purines and pyramidines. Therapeutic agents directed against nucleotide metabolism, urea cycle, and nitrogen excretion. Integration of metabolic pathways; biochemistry and nutrition; hormones and second messengers; hormonal control in metabolism; a case study in connectivity among metabolic pathways, nutrition, regulation and the immune system. Study of structure-function relationships and biological activity. Critical evaluation of results and identification of patterns or tendencies in observations. SLET.

General anatomy and physiology of livestock, that includes cell and tissue types and characteristics, body water, histology of tissues and organs, anatomy and physiology of systems and organs (skin, skeleton, muscles, connective tissue, nervous system, sensory organs of sight, sound, smell, touch, taste; circulatory system; respiratory system; endocrinology; male and female reproductive systems; digestive system, gastrointestinal tract, liver, pancreas; kidneys, acid-base balance and homeostasis; lactation; immune system). SLET with dissections of fresh material. Origin and development of soil, weathering and soil formation processes, profile differentiation and morphology, physical and chemical characteristics: texture, structure, soil water, atmosphere and temperature, clay minerals, ion exchange, $\mathrm{pH}$, buffer action, soil acidification and salinisation of soil, soil fertility and fertilization. Soil classification. SLET.

(continued on next page) 
Table 1 (continued)

\begin{tabular}{|c|c|c|}
\hline Year 2 & $\begin{array}{l}\text { Natural science } \\
\text { courses }\end{array}$ & Description \\
\hline & Genetics & $\begin{array}{l}\text { Introduction to molecular genetics, that includes gene structure, transcription and translation, gene regulation, DNA } \\
\text { replication, mutation, DNA repair and transposition, extra nuclear inheritance, genetic basis of cancer and immunity. } \\
\text { Creation of variation in micro-organisms, transformation, conjugation and transduction, basic concepts of recombinant } \\
\text { DNA technology and its applications in gene analysis and manipulation. Introduction to genetic analysis of populations: } \\
\text { allele and genotypic frequencies, breeding systems and quantitative inheritance. }\end{array}$ \\
\hline & $\begin{array}{l}\text { Introductory plant } \\
\text { production }\end{array}$ & $\begin{array}{l}\text { Introduction to plant production that includes sustainability in plant production, monoculture, crop rotation, lay } \\
\text { cropping, intercropping systems, organic farming, precision farming, and concepts of target yield, maximum economic } \\
\text { yield, farming systems approach, soil cultivation and conservation. }\end{array}$ \\
\hline & General nutrition & $\begin{array}{l}\text { Introduction to nutrition in the context of growth, development and composition of organisms, metabolism and control } \\
\text { in the body, nutritional processes, fundamental principles of nutrient metabolism and digestion physiology, } \\
\text { applications with regard to humans and animals. SLET. }\end{array}$ \\
\hline & Animal science & $\begin{array}{l}\text { Introduction to livestock production systems (large stock, small stock, pigs, poultry) and principles of nutrition, } \\
\text { breeding, production and products, general husbandry, livestock in the environment and livestock compatibility with } \\
\text { an environment, animal handling. }\end{array}$ \\
\hline & Agro climatology & $\begin{array}{l}\text { Climate in Southern Africa. Irradiation and energy balance. Hydrological cycle with special reference to downpour and } \\
\text { evaporation from vegetative surfaces. Wind-breaks and frost control. Influence of climate on farming systems. } \\
\text { Instrumentation and measurement of downpour, evaporation, radiation, temperature, humidity and wind. }\end{array}$ \\
\hline & \multicolumn{2}{|l|}{ Other courses } \\
\hline & Agricultural economics & $\begin{array}{l}\text { Introduction financial management in agriculture: Farm management and agricultural finance, farm management } \\
\text { information; analysis and interpretation of farm financial statements; risk and farm planning. Budgets: partial, break- } \\
\text { even, enterprise, total cash-flow and capital budgets. Time value of money. }\end{array}$ \\
\hline
\end{tabular}

Year 3 Natural science courses

Biometry

Analysis of variance: Multi-way classification. Testing of model assumptions, graphics. Multiple comparisons. Fixed, stochastic and mixed effect models. Block experiments. Estimation of effects. Experimental design: Principles of experimental design. Factorial experiments: Confounding, single degree of freedom approach, hierarchical classification. Balanced and unbalanced designs. Split-plot designs. Analysis of covariance. Computer literacy: Writing and interpretation of computer programmes. Report writing.

Animal science functional Functional anatomy, growth and development of tissues and organ systems. Changes during maturation, reproduction, the anatomy post-partum period and lactation. Ageing and tissue changes with erosion diseases. The influence of hormones, production and reproduction on conformation and a critical evaluation of assessment of animals for functional efficiency. SLET.

Animal science functional physiology

Physiology in terms of adaptation, metabolism, growth, reproduction and production that includes homeostasis and homeorhesis, thermoregulation, glucose, lipid and protein metabolism in response to short and long-term changes in the supply and balance of nutrients and to changes in tissue demand for nutrients during different physiological states, deviations from normal homeostasis, metabolic diseases and the prevention thereof, pathogenesis of inflammation and infections, immunity.

Reproduction that includes theriogenology, spermatogenesis, zoogenesis. Female sexual physiology, puberty, fertility, species differences, regulated fertility, oestrus observation, determination of gestation, collection of ova and in vitro fertilization, embryo collection, conservation and transfer, birth process, lactation physiology. Male sexual physiology, puberty, libido, fertility, semen collection techniques, the evaluation, dilution and conservation of semen, artificial insemination. Handling of apparatus and practical insemination.

Growth physiology that includes physiological processes in growth and development, pre-natal and post-natal growth, factors that determine growth rate and growth curves, growth manipulation in terms of age, nutrition, breed and production type, gender, nutrition, pharmaceuticals and other interventions. SLET.

Animal science nutrition A detailed course that includes digestion and metabolism of feeds, the division of food energy and food energy systems, protein quality and requirements, minerals and vitamins, nutritional standards, intake and passage, water quality, fodder characteristics, rumen function and microbial fermentation, practical in vivo and in vitro digestibility studies. SLET.

Principles of range management Biotic and abiotic factors effects on productivity of different strata and components of natural pastures and effects of management practices on sustainable animal production from natural pastures.

Animal science breeding A detailed course on animal breeding and genetics that includes karyotype of farm animals, breed and specie differences and genetics and influence on classification of breeds, influence of chromosomal aberrations, phenotypic expression of genes and gene-interaction in farm animals, single gene, major genes and polygenes, variation in traits of economic importance and statistical description, use of genetic variation, estimation of breeding values and family indices on traits determined by single genes, principles of breeding systems.

Animal science ecology An applied course in animal ecology and interactions between genotypes and environments that includes animal ecology factors that must be taken into consideration in planning and managing a farming enterprise and that extends to conservation farming, adapted farming and management systems. SLET.

Animal science Application of biotechnology in farm animals with specific reference to reproductive biotechnology such as AI MOET biotechnology and sex manipulation, which has an effect on genetic progress, application of DNA technology such as parentage verifications, identification of genetic defects, QTL's and MAS. SLET.

Planted pastures and fodder Establishment and use of planted pastures species and fodder crops and the conservation of fodder. crops

Year 4 Natural science courses

Large stock science

General husbandry of large stock that includes management practices, business management of an enterprise, production systems and techniques applicable to beef cattle, dairy cattle and horses, design and planning of farm facilities, storage and handling of feeds and refuse, and herd health programmes. 
Table 1 (continued)

\begin{tabular}{|c|c|c|}
\hline Year 4 & $\begin{array}{l}\text { Natural science } \\
\text { courses }\end{array}$ & Description \\
\hline & Poultry science & $\begin{array}{l}\text { General husbandry of production and feeding systems in poultry production units, that include applied breeding of } \\
\text { poultry, design and utilization of equipment and housing facilities, product quality and marketing of poultry products, } \\
\text { hygiene and health programmes. SLET. }\end{array}$ \\
\hline & $\begin{array}{l}\text { Animal science breeding } \\
\text { and genetics }\end{array}$ & $\begin{array}{l}\text { Applied animal breeding and genetics that includes components of animal performance, sources of variation, } \\
\text { population parameters and the estimation thereof, introduction to matrix algebra for application in animal breeding, } \\
\text { selection indices theory, statistical models in estimation of breeding values, application of breeding values and } \\
\text { prerequisites for accuracy, breeding and selection for reproduction and growth, principles of QTLs. Formulation and } \\
\text { application of breeding objectives, animal recording systems and international guidelines for evaluation, specie-specific } \\
\text { breeding systems, traits of economic impotence and the efficiency thereof, crossbreeding systems in meat producing } \\
\text { farm animals, breed development. SLET with computer models. }\end{array}$ \\
\hline & Animal science nutrition & $\begin{array}{l}\text { Applied nutrition of beef and dairy cattle, monogastric animals (poultry, ostriches, pigs, horses, selected freshwater } \\
\text { aquatic organisms, dogs and cats), small stock (sheep and goats) and game according to production systems. Compiling } \\
\text { rations in terms of production requirements and least cost formulations, supplementary nutrition on extensive } \\
\text { production systems, and specialised assignments with on-farm experiential training. SLET. }\end{array}$ \\
\hline & $\begin{array}{l}\text { Animal science } \\
\text { pharmacology }\end{array}$ & $\begin{array}{l}\text { Principles of pharmacology, regulations governing the use of pharmaceuticals, classifications and scheduling, types of } \\
\text { substances and their application for animal production. }\end{array}$ \\
\hline & Animal fibre science & $\begin{array}{l}\text { Characteristics of wool and mohair that include factors affecting growth, morphology, physical and chemical properties, } \\
\text { classing, marketing and processing, physical testing and class standards. SLET. }\end{array}$ \\
\hline & Small stock science & $\begin{array}{l}\text { General husbandry of small stock management systems that include applied nutrition, shearing, sheds and equipment, } \\
\text { pens, dipping, drinking and feeding facilities, preparation and marketing of skins, mohair and karakul, planned } \\
\text { production, lambing / kidding seasons, management programmes for wool, meat karakul pelt and mohair production } \\
\text { according to ecological regions and for conditions of drought, health programmes. SLET. }\end{array}$ \\
\hline & Pig Science & $\begin{array}{l}\text { General husbandry of pigs that include sow, boar and growing pigs, production systems, feeding systems, facilities, } \\
\text { product quality, marketing, hygiene and herd health programmes. SLET. }\end{array}$ \\
\hline & Meat and dairy science & $\begin{array}{l}\text { The meat industry, meat species, carcass and meat quality, slaughtering processes, consumerism. The dairy industry, } \\
\text { composition and nutritional value of milk and factors that influence it, milk production, milk quality, processing, } \\
\text { distribution. SLET. }\end{array}$ \\
\hline & Wildlife science & $\begin{array}{l}\text { Introductory aspects of wildlife conservation, habitat management, wildlife nutrition and keeping wildlife in zoological } \\
\text { gardens. }\end{array}$ \\
\hline & $\begin{array}{l}\text { Animal science scientific } \\
\text { literature }\end{array}$ & $\begin{array}{l}\text { Literature studies in animal science that include identifying a topic to review within the animal science domain, } \\
\text { sourcing scientific literature and information, interpreting and integrating scientific information, writing a science } \\
\text { review paper in science journal format, doing an oral and PowerPoint presentation. }\end{array}$ \\
\hline & $\begin{array}{l}\text { Animal science research } \\
\text { methodology }\end{array}$ & $\begin{array}{l}\text { Research methodology in animal science that includes identifying research objectives, scientific justification, } \\
\text { experimental design, laboratory and data analyses, interpreting and reporting results, referencing, ethics in research, } \\
\text { intellectual property, publishing, compiling and presenting a research proposal and report. }\end{array}$ \\
\hline
\end{tabular}

flexible programme without compromising on academic standards.

The MSc in animal science should in essence be a researchbased degree. However at this level students may require a further in-depth study of the respective field (nutrition, breeding and genetics, etc). To accommodate this, the criteria set by the SACNASP for a masters degree is a minimum of $50 \%$ credits for theory and a minimum of $50 \%$ credits for the research component. Advantages of the programme are: (i) it can be done part time; (ii) it relies on accumulated credits; (iii) it can be tailored for the candidate's specific require- ments. A master's programme consisting only of course work is, however, not acceptable.

\subsubsection{Doctorate degree}

The other aspect of graduate education is that which leads to research degrees, the doctor of philosophy (Holt, 1987). The $\mathrm{PhD}$ programme should remain a research degree. There is no better way for a candidate to establish an expertise in a field than by research. The thesis should convey the candidate's knowledge-base through an appropriate review and discussion of the relevant literature, define and test one

Table 2

Vertically structured qualifications in the animal sciences offering three outcome levels: two-year diploma, three-year degree and four-year professional degree.

\begin{tabular}{lll}
\hline Qualification & Admission requirements & Minimum study period \\
\hline Diploma in Agriculture & Conditional Grade 12 certificate & 2 years \\
Baccalaureus Agriculturae: BAgric & Conditional Grade 12 with mathematics & 3 years \\
Baccalaureus Agriculturae: BAgric & Conditional migration from the Diploma in Agriculture & 3 years \\
Baccalaureus Scientiae Agriculturae: BSc (Agric) & Conditional Grade 12 with higher grade mathematics & 4 years \\
& or a C-symbol in standard grade mathematics, & \\
Baccalaureus Scientiae Agriculturae: BSc (Agric) & and Grade 12 Science and/or Biology & 4 years \\
\hline
\end{tabular}


or more hypotheses, and present a detailed evaluation of the results in terms of the relevant literature. Although the thesis is a scientific publication, the process of publishing the research should not be considered completed until an article has been published in a peer reviewed science journal, and where appropriate a communication disseminated to the industry through the industry-related printed or electronic media.

Proven expertise and standards are the criteria according to which students should select a particular university for an advanced degree. It is in students' interests to spend time on establishing a university's credibility before registering. Students and funding bodies should be careful not to be lured by catch-phrase names for degrees and should also be careful about a terminal master's programme.

Kauffman (1992) noted that to ensure that curricula continue to improve, the following should prevail:

- students must be adequately prepared before starting an animal science programme,

- teachers must keep abreast with needs of the industry by conducting research and serving the public,

- instructors must maintain flexibility in subjects to meet needs of industry and interests and aptitudes of students,

- unless all prerequisites have been completed, it is realistic to expect that 9 to 10 semesters will be needed to complete a programme,

- science students should be required to complete a thesis problem followed by a seminar, and business students should be required to complete a project followed by a report,

- a qualifying comprehensive examination should climax the programme to ensure credibility of both the graduate and the programme.

\section{Lecturers and researchers}

What should the profile be of the academic? For an answer to this question one must consider the role of a university. In its simplest definition, a university has come to mean a place of higher learning, with the right to distinguish between and recognise levels of learning and to confer degrees as such which certify the knowledge and competency of the graduates. That's very formal. My own view is that a university should be a place of discovery-discovery of the wonders of science and philosophy, discovery of values, discovery of the self, and discovery of social interaction. The academic in the simplest terms is a teacher, an expounder of knowledge. In the classical sense the teacher is the philosopher who explores the unknown. Socrates is known to have adopted the method of question and answer, the dialectic method. In its literal sense the dialectic is a procedure towards logical deduction. The university teacher must therefore also be the discoverer, the researcher. The university lecturer must be the discoverer who draws students in to develop knowledge, gain philosophical insight and express creativity.

The adage that rulers should also know the art of ruling is attributed to Socrates. Is it therefore correct that teachers should know the art of teaching? The acceptance of this has lead to training at universities and colleges in pedagogic.
However, few academics have ever been exposed to, let alone trained in, any pedagogical procedures. Courses in teaching methodology are not to doubt the lecturer's knowledge-base, but to better equip the person to transfer or instil knowledge in students, and to be up-to-date with technological advances in teaching aids.

The style of communication also has a cultural base, which van den Bor (1996) notes, and that can become a complicating factor. Cultural differences must be noted and if necessary, catered for in the university environment. Prejudices can be neutralised through a focussed, scientific and philosophical environment that would prepare the graduate to function in this manner in industry. Since graduates are being prepared for a life-long career with its challenges and changing technologies, the procedure of logical deduction should be imbued in first degree graduates. Students should understand that the education they receive is only a means to end, and not an end in itself.

The celebrated author and humanist, Alan Paton said "A university education can furnish one with tools to go on working and thinking and researching, but whether it does so depends not on the university, but on the persons lucky enough to go there" (Paton, 1985).

The demands and expectations of a university lecturer are therefore high. The person is expected to be a competent teacher and a proven researcher-two inseparable attributes. The question arising from this is: Are the conditions at universities conducive for excellence in teaching and research? A current general interpretation regarding animal science is: certainly not. Teaching loads are high, research facilities become outdated and there is a constant shortage of research support personnel.

Animal science is an expensive discipline requiring laboratories and animal housing and handling facilities. In some countries universities have to compete with government institutions for resources. Many policy makers consider there should be greater integration between universities and research institutes. In reality, integration does not easily happen due to differences in their mandates and institutional cultures. The consequence, is dilution of resources. Promoting centres of scientific excellence at universities should be an objective of government policies on science, engineering and technology.

The profile of the academic should be one with a philosophical insight due to his/her knowledge, be creatively questioning, technically competent in the discipline and have the ability to guide (not teach) the students along the right track into their careers.

\section{Inter-university exchange and internationalisation of animal science curricula}

Sub-Saharan Africa abounds with universities teaching animal agriculture. Unfortunately there is little cooperation and communication between them. The roots of the problem lay in the history of Africa and in particular the colonial history. A survey of the internationalisation of undergraduate animal science curricula in North America revealed that the concept was widely supported in principle, but the implementation was limited due to particular factors, of which finance was the critical determinant. Where it did occur, 
tangible advantages accrued to both faculty staff and students (Forsberg et al., 2003).

In Africa, barriers are financial and language (for example, Francophone, Portuguese and Anglophone countries) and academic years do not coincide. Standardised curricula, exchanging lecturers, sharing examiners and cooperative research projects would be mutually beneficial to the respective universities. Human interaction is the critical source of intangible value in the intellectual age (O'Donnell et al., 2003). This would enhance the IC required to practice animal science throughout the continent.

\section{Continual professional development programmes}

The IC gained at university is among the first steps on the professional ladder. The IC required for a sustained, life-long career development is an accumulative process that cannot rely on passive acquisition of IC through experience. The investment in IC must be deliberate. This offers collaborative opportunities to universities, professional science societies and the industry. At this point the focus moves from that of conventional undergraduate and postgraduate education programmes to professional development programmes that, as Roos et al. (1997) and O'Donnell et al. (2003) noted, are to facilitate the leverage of IC into economic and social value.

\section{Conclusions}

The IC of the livestock industry and the animal science profession has accrued since the first steps were directed at the improvement of livestock by Robert Bakewell. Accumulated IC in animal science has successfully contributed to developing an efficient global industry, but that has come at a cost. The challenge is to develop the IC by which to address the negative aspects of the livestock industry, to the advantage of humankind and the environment. The IC within the livestock industry was gained from traditional knowledge and from the natural sciences, economic sciences and social sciences. Investments in IC to sustain the livestock industry must therefore not only be technical of an animal science nature, but should include external constituencies such customers, suppliers, strategic alliances, research institutes and others. IC is required at different levels that range from labourers to university science graduates. Undergraduate and postgraduate education in animal science must be designed to meet the objectives of a sustained career development and the ability to address the challenges facing the livestock industry. There need not be only one type of graduate, but curricula can be adapted to provide graduates with a different focus. Clearly defined output objectives of curricula should be designed in consultation with the industry. IC and professional development programmes would benefit from unconditional cooperative programmes between universities, professional science societies and the industry. The future of the animal industry is dependent on the effective acquisition and application of the appropriate IC.

\section{References}

Act 27, 2003. Natural Scientific Professions Act: Act No 27 of 2003. Government Gazette, 461, 25774, 1-32.
Braund, D.G., 1995. Changing paradigms in animal agriculture: the role of academia and industry in technology transfer. J. Anim. Sci. 73, 3173-3177.

Casey, N.H. 1993. African horizons in animal and wildlife sciences. Inaugural lecture: Professor and Head of Department, Department of Animal and Wildlife Sciences, University of Pretoria, 6 May 1993. Inaugural Publications, University of Pretoria, No 284, ISBN 0-86979-761-1, pp 9.

Casey, N.H., 1996. Training and education for the animal agriculture industry. Food security in Africa-challenges, opportunities and targets for Animal Production in Africa. Proceedings: 2nd All Africa Conference on Animal Agriculture, 1-4 April 1996. ISBN: 0620200537, pp. 325-337.

Chickering, A. 1996. Empowering lifelong self-development. UP-dosent (ISBN 0258-7408). 17, 3-10.

De Lange, A.O., 1988. Veekundige opleiding in Suid-Afrika. (Abs.). Anim. Sci. 27, 2-9.

Forsberg, N.E., Taur, J.S., Xiao, Y., Chesbrough, H., 2003. Internationalization of the animal science undergraduate curriculum: a survey of its current status, barriers to its implementation and its value. J. Anim. Sci. 81 (4), 1088-1094.

Gilchrist, F.M.C., 1988. The training of professional animal scientists. Presidential Address, 27th Congress of the South African Society of Animal Production. Anim. Sci. 27 (2), 3-5.

Gous, R.M., 2009. Nutritional limitations on growth and development in poultry. Livestock Science.

Griessel, M., 1988. The training of animal scientists for the animal feed industry. Anim. Sci. 27 (2), 11-12.

Hirschowitz, R., 1986. The work situation of a group of agricultural scientists. Institute for manpower research, Human Sciences Research Council. Anim. Sci. 24 (1), 4-5.

Holt, R.T., 1987. Human capital needs for graduate training. Proceedings, 40th Annual Reciprocal Meat Conference, pp. 1-4.

Honeyman, M.S., Miller, G.S., 1998. The effect of teaching approaches on achievement and satisfaction of field-dependent and field-independent learners in animal science. J. Anim. Sci. 76 (6), 1710-1715.

Kauffman, R.G., 1992. Modernising that animal science curriculum-is change needed? J. Anim. Sci. 70 (8), 2593-2596.

Kingwill, P.E., 1996. Medium and large animal enterprises in South Africa. Proceedings, 2nd All Africa Conference on Animal Agriculture, 1-4 April 1996, Pretoria, South Africa. ISBN: 0620200537, pp. 241-246.

Lombard, J.H., 1988. Die behoefte van die vleisbedryf met betrekking tot die opleiding van veekundiges. Anim. Sci. 27 (2), 10-11.

Macadam, R.D., Bawden, R.J., 1985. Challenge and response: developing a system for educating more effective agriculturalists. Prometheus 3 , $125-137$.

O'Donnell, D., O'Reagan, P., Coates, B., Kennedy, T., 2003. Human interaction: the critical source of intangible value. J. Intellect. Capital 4 (1), 82-99.

Orr, C.L., 1996. Communication across the curriculum in animal science. J. Anim. Sci. 74 (11), 2828-2834.

Paton, A. 1985. Address before the Witwatersrand branch of the Alumnus Association of the University of Natal.

Richardson, F.D., 1988. The training of animal scientists in different countries. (Abs.). Anim. Sci. 27 (2), 9.

Roos, J., Roos, G., Edvinsson, L., Dragonetti, N.C., 1997. Intellectual capital: navigating in the new business landscape. Macmillan, London.

SACNASP, 2009. Executive Committee, South African Council for Natural Scientific Professions, resolution EC08/2009, 8.3.

Steinfeld, H., Gerber, P., Wassenaar, T., Castel, V., Rosales, M., de Haan, C., 2006. Livestock's long shadow-environmental issues and options. Food and Agricultural Organisation (FAO), United Nations, Rome, Italy9251055718.

Stielau, W., 1989. The animal scientists in training. Anim. Sci. 28 (3), 3-14.

Sullivan, P., 2000. Value Driven Intellectual Capital: How to Convert Intangible Corporate Assets into Market Value. Wiley/Arthur Anderson Intellectual Capital Series0471351040.

Swanepoel, F.J., 1990. Training of animal scientists for the developing areas. Anim. Sci. 29 (4), 10-11.

Swanson, J.C., 1999. What are animal science departments doing to address contemporary issues? J. Anim. Sci. 77 (2), 354-360.

U.O.F.S. Yearbook, 2010. University of the Free State, Faculty of Natural and Agricultural Sciences, Yearbook 2010: Part 4: Agricultural Sciences: Undergraduate Programmes.

U.P. Yearbook, 2009. University of Pretoria, Faculty of Natural and Agricultural Sciences, Yearbook 2009, pp 113-116.

Van den Bor, W. 1996. Higher agricultural education and rural restructuring in the Republic of South Africa. Series of seminars presented in the RSA.

Vosloo, L.P., van der Merwe, F.J., 1976. Aspekte in verband met die opleiding van 'n professionele veekundige. Proceedings of Symposium on Professional Animal Scientists, pp. 4-6 (10 August 1976).

Webb, E.C., Casey, N.H., 2009. Physiological limitations to growth and the related effects on meat quality. Livestock Science. 
Weber, G.M., Hoban, T.J., Kendall, P.A., Bull, L.S., 1995. Consumer concerns about modern technology in agriculture: considerations for undergraduate and graduate teaching. J. Anim. Sci. 73, 2727-2732.

Westendorf, M.L., Zimbelman, R.G., Pray, C.E., 1995. Science and agriculture policy at land-grant institutions. J. Anim. Sci. 73, 1628-1638.

Wilke, P.I., 1992. The training of animal scientists: elements of rationalisation. S. Afr. Jnl. Higher Educ. 6 (2), 55-58.
Wood, R.J., Orel, V., 2005. Scientific breeding in Central Europe during the early nineteenth century: background to Mendel's later work. J. Hist. Biol. 38, 239-272.

World Bank Report No 44010-GLB, 2009. Minding the stock: bringing public policy to bear on livestock sector development. The World Bank, Agriculture and Rural Development Department. 